\title{
The current need to continue researching with embryonic stem cell
}

\section{A necessidade atual em se continuar a pesquisar com células-tronco embrionárias}

\author{
Braulio Fernandes de Carvalho ${ }^{1,2}$, Ingridi de Souza Sene ${ }^{3}$, Ana Luiza Fernandes de Carvalho ${ }^{4}$, \\ Paula Andrea Sampaio de Vasconcelos ${ }^{5}$ \\ ${ }^{1}$ Tsukuba University, Ibaraki, Japão \\ ${ }^{2}$ Research Center for Stem Cell Engineering - National Institute of Advanced Industrial Science and Technology - AIST, Ibaraki, Japão \\ ${ }^{3}$ Laboratório Lapac, Teresina, Brasil \\ ${ }^{4}$ UNINOVAFAPI, Teresina, Brasil \\ 5 Universidade Estadual Paulista - UNESP, Botucatu, Brasil
}

\begin{abstract}
Embryonic stem cells are pluripotent and able to generate all cell types of the body, being the most promising cells to the study for regenerative medicine. Following the differentiation path, there are adult stem cells, which are committed with a specific cell lineage, creating limitations on their application. On the extreme opposite of embryonic stem cells there are the induced pluripotent stem cells, originated from a somatic cell after genetic reprogramming. Induced pluripotent stem cells are a recent science discovery and may substitute the use of embryonic stem cells in future research. But with nowadays knowledge, the use of adult stem cells and induced pluripotent stem cells are limited due to high expenses and long time process demand. Moreover, the development achieved on all kinds of stem cells study are, in some part, due to the study of embryonic stem cells, what makes the study of these cell type still mandatory.
\end{abstract}

Keywords: stem cells, cell differentiation, cell dedifferentiation.

\section{RESUMO}

Células-tronco embrionárias são pluripotentes e com potencial de se diferenciar em todos os tipos celulares do corpo, sendo, por isso, as células mais promissoras para pesquisa em medicina regenerativa. Seguindo o processo de diferenciação há as células-tronco adultas, que já estão comprometidas com uma linhagem celular específica, o que cria limitações ao seu uso. No extremo oposto das células-tronco embrionárias têm-se as células-tronco pluripotentes induzidas, originadas a partir de uma célula somática após reprogramação genética. As células-tronco pluripotentes induzidas são uma recente descoberta da ciência em pesquisa celular e um dia podem substituir as células-tronco embrionárias na aplicação em pesquisa. Mas com o conhecimento atual a utilização de células-tronco pluripotentes induzidas é limitada pelos altos custos e longo processo. Além do mais, o desenvolvimento alcançado com os demais tipos de células-tronco se deve, em parte, ao estudo com células-tronco embrionárias, o que de certa forma ainda obriga a continuidade de investigação com esse tipo celular.

Palavras-chave: células-tronco, diferenciação celular, desdiferenciação celular.

The biology considers stem cells as those capable of differentiating into various types of cell, including making copies of themselves, as well as repairing damaged tissues and injuries. They are classified as embryonic, adult and indu- ced pluripotent stem cells. Embryonic stem cells (ESCs) are obtained from the internal mass of the blastocyst and are able to originate all cells of the body. Due to this large differentiation capacity, these cells are the most promising ones to the investigation in regenerative medicine. ESCs are also able to remain in culture, under the right stimulation, for undefined cycles without losing the pluripotential property. But this huge broad of possibilities is also the factor that makes their use dangerous: it might lead to teratoma formation if cells are not properly differentiated (Klimanskaya et al., 2006; Kurisaki \& Asashima, 2009). In fact, to confirm if some cells are ESCs or ESC-like they should form teratoma when implanted into immune-deficient mouse. But what is the best protocol to assure differentiation? Should it be considered morphology, genetic and protein expression, molecular markers or metabolism? Besides, there are several ethical issues concerning the use of ESCs obtained from human embryos, mostly because the destruction of the embryo was enforced.

The pre-implantation genetic diagnosis (PGD) is a technique that allows the removal of a single blastomere from the blastocyst without its destruction. The improvement and spreading of the PGD technique might enable researching human ESCs without embryo destruction a common application and cease or, leastways, reduce the ethical concerns of embryo usage. The removal of one single blastomere from the embryo doesn't affect its development neither the natural evolution of the pregnancy (Klimanskaya et al., 2006). The success of the PGD, though, relies at the ability of the embryologist and the culture derived from human single blastomere stills of hard reproducibility.

The other type of stem cells are the adult stem cells (ASCs), which are already compromised with some specific cell line and are not able to remain longer in culture without losing their properties (due to aging and natural differentiation). ASCs are easier to obtain than ESCs, since they can be found in almost all human tissues, including blood, skin and fat. Also, studies report the capacity to use ASCs to obtain an origin-different tissue, despite its natural limited differentiation potential (Piek et al., 1999; Kurisaki \& Asashima, 2009). This process is possible by changing the external environment surrounding ASCs, called the niche effect.

ASCs have less capacity to produce teratomas and do not use viral reprogramming, what makes them safer than ESCs and induced pluripotent stem cells (iPSCs). The reprogramming of ASCs depends on finding the proper external stimuli to manipulate cells characteristics (Miki et al., 2005). Although it's difficult to find the specific combination of compounds to each ASCs type, it's also the huge 
variety of ASCs and sources that brings a lot of application possibilities for these cells into regenerative medicine and organ development.

Another advantage of ASCs is those can be found in human organic disposable material, such as the pulp of removed teeth, the fat of liposuction or the placenta and amniotic sac obtained after normal birth delivery. From the placenta and amniotic sac several populations of stem cells can be obtained: mesenchymal, hematopoietic, trophoblastic, epithelial and maybe some more primitive stem cells. The amniotic sac itself is of extreme importance, since it has origin in the embryonic epiblast before the gastrulation, which is the first important event of determining cellular differentiation fate. Because of that it was speculated that these cells must retain some ESC-like properties, what is being confirmed in several studies (Bailo et al., 2004; Miki et al., 2005).

The most studied ASCs till now are the mesenchymal stem cells, especially because they can be isolated from various tissues, such as adipose tissue, peripheral blood, umbilical cord, amniotic fluid and amniotic sac. The mesenchymal stem cells generate a lot of expectations due to their multilineage differentiation capacity, their immunomodulatory properties and their ability to secrete bioactive molecules (Dominici et al., 2006). Among those bioactive molecules are the cytokines, molecules involved at the immunomodulatory and inflammatory activites and also capable of mobilizing local tissue ASCs through environmental modulation. It means that, even if the graft of transplanted stem cells doesn't implant in the tissue, it stills be beneficial producing bioactive molecules that are able to accelerate the healing of injured site (Zhao et al., 2004; Kamiya et al., 2005).

The most recent and one of the greatest discoveries in recent stem cell research field are the iPSCs, which gave Yamanaka et al. (2007) the Nobel Prize in Physiology or Medicine at 2012. iPSCs are mature cells that have been backprogramed to behave like an ESCs. A somatic cell, which is a compromised cell, is converted back to an ESC-like stage. This process involves the expression of genes into somatic cells that normally would be silent, but are active in ESCs and in cancer cells. Likely ESCs, iPSCs can lead to teratoma or cancer formation (Sumitomo et al., 2000; dos Santos et al., 2008; Pinto et al., 2009). In the mean time, the biggest advantage of iPSCs is the fact they can be originated from any cell of the body as, for example, dermal epithelial cells. Unfortunately, converting a somatic cell into an iPSCs is an expensive, complex and prolonged procedure (Nakanishi et al., 2008).

The use of ASCs and iPSCs might represent a revolution on regenerative medicine. It could make possible to treat a patient who need an organ donation, using cells from the own patient to repair the body (Kurisaki et al., 2010). There would represent the end of organ donation waiting, tissue rejection and embryo use (Takehara-Kasamatsu et al., 2007). And to the pharmacologic research it represents a breakthrough. Imagine a person with some disease of the brain cells. Normally, obtaining brain cells from this person would be a tremendous effort but collecting adult stem cells or even somatic cells from the skin would be a much simpler procedure. Than these cells could be differentiated into brain cells, like neuronal or glial cells, and allow researching at a reliable disease model, with the same genetic material of the patient. The personalized medicine is becoming tangible.

All that new information lead to the questioning: with all the possibilities and new discoveries involving ASCs and iPSCs research, is it still necessary to use ESCs? To answer this question it is important to understand that the successful development of ASCs and iPSCs researches is quite recent, as well as into ESCs research field. And these discoveries just became possible after the early understanding afforded by all researches with ESCs (Asashima et al., 2008). iPSCs were developed by mimicking ESCs genetic expression and ESCs molecular markers and proteins became a great guide into ASCs research.

Despite the importance of ESCs research, several countries face limitations to keep developing their studies. In the United States (2001) the President Bush administration decided to restrict federal funding through the National Institutes of Health (NIH) to researches using human ESCs lines (Schlaeger et al., 2007). Although President Obama lifted Bush administration's restrictive policy in 2009 (Holden, 2009) the country continues to encounter problems derived from those restrictions, as the limitation of access to new ESCs lines. Since then the president Obama invested massively into ESCs research and proposed to tax researches involving embryo destruction. Despite his protective proposal, several groups appealed legally to U.S. Supreme Court to review Obama's permission.

In Italy the situation is even more complex. Italy's laws, said to be the most restrictive in Europe, were passed in December of 2003 and forbid embryo freezing, gamete donation, surrogacy, and the provision of any fertility treatments for single women or same-sex couples. Italy's laws also say that no more than three eggs can be fertilized at any one time, and that any eggs fertilized must all be transferred to the uterus simultaneously, increasing the risk of multiple births. PGD and prenatal screening for genetic disorders are banned (Bionews, 2005; Nature. 2009). This action creates problems to clinics of IVF and to Italian scientists, which have no embryos or blastomeres to research. Politicians are also cutting funding to researches related to ESCs.

The new Brazilian Law of Biosecurity do not aim to restrict the use of ESCs and ASCs, but intends to regulate the manipulation of these cells, assuring the ethical and responsible application and preventing any condemnable usage. The old Brazilian Law of Biosecurity $n^{\circ} 8.974 / 95$ (Art. 13), revoked by the current Law $n^{\circ} 11.105 / 2005$, expressly and totally prohibited the use or manipulation of human germinal cells, being extremely restrictive to scientific research (Ghizelini et al., 2007).

Brazil is in a very special position among the countries with full potential to take the leadership of the stem cell research. Indeed, Brazilian scientists are starting to get recognition, especially to researches related to the use of stem cells to treat diabetes, with some patients already free of external insulin administration (Voltarelli et al., 2009).

In the future, researches using human ESCs might not be necessary but, at the current moment, investing on ESCs studies is still a priority. And, in between, hardly invest onto other sources of stem cell, such as ASCs and iPSCs, animal model and genetic development. If nowadays discoveries at stem cell research field are quite recent but already astonishing, imagine how much more can be achieved with the comprehension of the DNA and RNA expression, the interaction and cooperation of research centers among the world, the growing understanding of the genoma and of the genetic evolution. Softwares and hardwares are being developed and might, in a few years, produce standardized stem cells lines in large scale, reducing the costs and making them more accessible. New drugs, new treatments and new cures are starting to be developed and much more is about to come. Today's medicine is living the most exciting and revolutionary moment since the discovery of penicillin.

\section{Corresponding author}

Bráulio Fernandes de Carvalho

Telefone: +81 (080) 3170 - 8546 (Japão)

Email: hazbio@gmail.com

CARVALHO Bráulio Fernandes de

Stem Cell Differentiation Research Team, Research Center for Stem Cell Engineering, National Institute for Advanced Industrial Science and Technology AIST Tsukuba Central 4-1- 3106 Higashi 1-1-1, Tsukuba, Ibaraki, Japan 305-8562

\section{REFERENCES}

Asashima M, Michiue T, Kurisaki A: Elucidation of the role of activin in organogenesis using a multiple organ induction system with amphibian and mouse undifferentiated cells in vitro. Dev Growth Differ. 2008; 50:(Suppl 1)S35-45.

Bailo M, Soncini M, Vertua E, Signoroni PB, Sanzone S, Lombardi G, Arienti D, Calamani F, Zatti D, Paul P, Albertini A, Zorzi F, et al. 
Engraftment potential of human amnion and chorion cells derived from term placenta. Transplantation 2004; 78:1439-1448. Bionews. The fate of frozen embryos under the Italian fertility law. 2005; 314.

Dominici M, Le Blanc K, Mueller I, Slaper-Cortenbach I, Marini F, Krause D, Deans R, Keating A, Prockop Dj, Horwitz E. Minimal criteria for defining multipotent mesenchymal stromal cells. The International Society for Cellular Therapy position statement. Cytotherapy .2006; 8(4): 315-317

dos Santos LG, Lopes-Costa PV, dos Santos AR, FACINA G, da Silva BB. Bcl-2 oncogene expression in estrogen receptor-positive and negative breast carcinoma. Eur J Gynaecol Oncol. 2008; 29:459-461.

Ghizelini RC, Monfroi J,Pauletti M. Alguns aspectos civis acerca da utilização de células-tronco. Rev Dir Públ. 2007; 2(3):65-82.

Holden C. Headaches ahead on stem cells. Science. 2009; 323: 1552-1553.

Kamiya K, Wang M, Uchida S, Amano S, Oshika T, Sakuragawa $\mathrm{N}$, Hori J. Topical application of culture supernatant from human amniotic epithelial cells suppresses inflammatory reactions in cornea. Exp Eye Res. 2005; 80:671-679.

Klimanskaya I, Chung Y, Becker $S$ et al. Human embryonic stem cell lines derived from single blastomeres. Nature. 2006; 444:481-485.

Kurisaki A, Asashima M. Approaches for standardization of stem cells. Industrial Applied Technology of Induced Pluripotent Stem Cells. CMC Press. 2009; 26-33.

Kurisaki A, Ito $Y$, Onuma $Y$, Intoh A, Asashima M. In vitro organogenesis using multipotent cells. Hum Cell. 2010; 23:1-14.

Miki T, Lehmann T, Cai H, Stolz DB, Strom SC. Stem cell characteristics of amniotic epithelial cells. Stem Cells 2005; 23:1549-1559.
Nakanishi M, Kurisaki A, Asashima M: Basic knowledge of ES cells and iPS cells. Pharmacia. 2008; 44:1047-1051.

Nature. Italians sue over stem cells. 2009; 146(19). doi:10.1038/460019a

Piek E, Moustakas A, Kurisaki A, Heldin $\mathrm{CH}$, and ten Dijke P: TGF-(beta) type I receptor/ALK-5 and Smad proteins mediate epithelial to mesenchymal transdifferentiation in NMuMG breast epithelial cells. J Cell Sci. 1999; 112:4557-4568.

Pinto LSS, de Aguiar Jr FCA, Kowalski LP, Graner E, Lopes MA. FAS and ErbB2 expression in early local recurrent oral cancer. J Oral Path and Med. 2009; 9999.

Schlaeger TM, Lensch MW, Taylor PL. Science aside: the trajectory of embryonic stem cell research in the USA. Drug Discov Today. 2007;12: 269-271.

Sumitomo K, Kurisaki A, Yamakawa N, Tsuchida K, Shimizu E, Sone S, Sugino H. Expression of a TGF-beta1 inducible gene, TSC-36, causes growth inhibition in human lung cancer cell lines. Cancer Lett. 2000; 155:37-46.

Takahashi K, Tanabe K, Ohnuki M, Narita M, Ichisaka T, Tomoda $\mathrm{K}$, Yamanaka S. Induction of pluripotent stem cells from adult human fibroblasts by defined factors. Cell. 2007; 131:861-872.

Takehara-Kasamatsu Y, Tsuchida K, Nakatani M, Murakami T, Kurisaki A, Hashimoto O, Ohuchi H, Kurose H, Mori K, Kagami S, Noji S, Sugino $\mathrm{H}$. Characterization of follistatin-related gene as a negative regulatory factor for activin family members during mouse heart development. J Med Invest. 2007; 54:276-288.

Voltarelli JC, Couri CEB, Rodrigues MC, Moraes DA, Stracieri $A B P L$, Pieroni $F$ et al .Terapia celular no diabetes mellitus. Rev. Bras. Hematol. Hemoter. 2009; 31:149-156.

Zhao RC, Liao LM, Han Q. Mechanisms of and perspectives on the mesenchymal stem cell in immunotherapy. J Lab Clin Med 2004 ; 143(5): 284-291 